\title{
Güneydoğu Anadolu Bölgesinde Aksiyel Spondiloartrit Hastalarının Klinik Özellikleri, Prognostik Faktörler ve Tedavi Yanıtlarının Değerlendirilmesi
}

Evaluation of Clinical Features, Prognostic Factors, and Treatment Responses of Patients with Axial Spondyloarthritis in Southeastern Anatolia

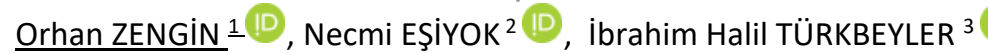

${ }^{1}$ Dr. Ersin Aslan Eğitim ve Araştırma Hastanesi, Romatoloji Bölümü, Gaziantep, TÜRKiYE

2 Şanlıurfa Sağlık Müdürlüğü, Personel Hizmetleri Başkanlığı, Şanlıurfa, TÜRKiYE

3 Dr. Ersin Aslan Eğitim ve Araştırma Hastanesi, Geriatri Bölümü, Gaziantep, TÜRKiYE

Öz.

Amaç: Spondiloartritler ; aksiyel tutulumun ön planda olduğu, ortak klinik, epidemiyolojik ve genetik özellikler bulunan bir grup hastalığı tanımlar. Spondiloartritlerde klinik, genetik ve çevresel faktörleri araştırmak etyopatogenezi anlamak açııından önemlidir. Aksiyel spondiloartritin ülkemiz verileri kısıtıdır. Biz bu çalışmada aksiyel spondiloartritin Güneydoğu Anadolu bölgesinde yer alan Adıyaman ili verilerini sunmayı amaçladık. Materyal ve metod: Adıyaman Eğitim ve Araştırma Hastanesi romatoloji kliniğinde takipli ASAS aksiyel spondiloartrit sınıflama kriterlerine göre tanı konulmus hastaların dosyaları retrospektif olarak tarandı. Hastalık takibinde Bath AS Hastalık Aktivite Indeksi (BASDAI), eritrosit sedimantasyon hIzI (ESR) ve c-reaktif protein (CRP) kullanıldı. Hastaların fonksiyonel durum değerlendirmesinde Bath AS Fonksiyonel İndeksi (BASFI) kullanıldı.

Bulgular: Çalışmaya toplam 308 hasta dahil edildi. Hastaların 181'i $(\% 58,8)$ erkek, 127'si $(\% 41,2)$ kadındı. Medyan (25-75 IQR) yaş 36 (31-45) idi. illk semptomdan tanı almalarına kadar geçen süre (tanıda gecikme süresi) medyan (25-75 IOR) 4 (3-5,5) yıldı. 110 hastada çalısılan HLA-B27 \% 43,6 oranında pozitifti. HLA-B27 pozitif olan hastalarda istatiksel anlamlı olarak erkek oranı $(\% 66,7, p=0,025)$ ve BASFI skoru daha yüksek $(p=0,019)$, tanıda gecikme süresi ise daha düşüktü $(p=0,015)$. Tümör nekrozis faktör inhibitörleri (Anti-TNF) ve Nonsteroid antiinflamatuar ilaç alan hasta grupları arasında klinik, laboratuvar, BASDAI ve BASFI parametrelerinde anlamlı farklıık yoktu. Sonuç: Spondiloartritler genç erişkinleri daha fazla etkiler. HLA-B27 ve erkek cinsiyet prognoz açııından önemlidir. Spondiloartritte konvansiyonel tedaviye yanıt olmadıs̆ında anti-TNF iyi bir seçenektir. Anti-TNF tedavi ile hastalık aktivitesi kontrol altına alınmakta ve hastaların fonksiyonel kapasiteleri artmaktadır.

Anahtar Kelimeler: Spondiloartrit, Anti-TNF, HLA-B27, Türkiye

Abstract

Background: Spondyloarthritis represents a group of diseases with common clinical, epidemiological, and genetic features, such as involvement of axial skeleton. To understand the etiopathogenesis of spondyloarthritis, we need to know its clinical, genetic, and environmental factors. Our country's data on axial spondyloarthritis is limited. In this study, we aimed to present the data of axial spondyloarthritis in Adıyaman in the Southeastern Anatolia region.

Materials and Methods: The medical records of patients diagnosed with axial spondyloarthritis were retrospectively reviewed according to the Assessment of SpondyloArthritis international Society classification criteria in the rheumatology clinic of Adıyaman Training and Research Hospital. The Bath AS Disease Activity Index (BASDAI), erythrocyte sedimentation rate, and c-reactive protein data were collected during the follow-up period. Bath AS Functional Index (BASFI) was used to evaluate the functional status of the patients.

Results: The study included a total of 308 patients, including $181(58.8 \%)$ males and $127(41.2 \%)$ females. The median (25-75 IQR) age was 36 (31-45) years. The median (25-75 IQR) time from the onset of symptoms to diagnosis (delay time in diagnosis) was $4(3-5,5)$ years. HLA-B27 was found positive in $43.6 \%$ of 110 patients studied. There was a significantly higher percentage of male patients $(66.7 \%, p=0.025)$ and a higher BASFI score $(p=0.019)$ among the HLA-B27-positive patients, and the delay time in diagnosis was lower $(p=0.015)$. There were no significant differences in the clinical, laboratory, BASDAI, and BASFI parameters between patients receiving nonsteroidal anti-inflammatory drugs and tumor necrosis factor inhibitors (anti-tumor necrosis factor [anti-TNF]).

Conclusion: Spondyloarthritis affects young adults more frequently. HLA-B27 status and male gender are important for prognosis. Anti-TNF therapy is a good option when there is no response to conventional treatment in spondyloarthritis. Disease activity is controlled and patients' functional capacities are increased with anti-TNF treatment.

Key words: Spondyloarthritis, anti-TNF, HLA-B27, Turkey
Sorumlu Yazar / Corresponding Author

Dr. Orhan ZENGIN

Dr. Ersin Aslan Eğitim ve Araştırma Hastanesi, Romatoloji Bölümü, Gazi Muhtar Paşa Blv. No:37, 27090, Şehitkamil / Gaziantep, TÜRKIYE

E-mail: drorhanzengin@gmail.com Geliş tarihi / Received: 02.07.2020 Kabul tarihi / Accepted: 25.11.2020 DOI: $10.35440 /$ hutfd.763049 


\section{Giriş}

Spondiloartritler (SpA); aksiyel tutulumun ön planda olduğu, ortak klinik, epidemiyolojik ve genetik özellikleri bulunan bir grup hastalığı tanımlar. Ankilozan spondilit (AS), psöriatik artrit (PsA), reaktif artrit, enteropatik artrit ve belirlenemeyen SpA günümüzde spondiloartritler içerisinde sayılan belli başlı hastalıklardır. Erkek baskınlığı, entezit, sakroiliak eklem tutulumu, asimetrik oligoartrit ve HLA-B27 ile güçlü ilişki bu ortak özelliklerin önde gelenleridir (1). SpA grubu hastalıklar klinik özelliklerine göre iki alt grupta incelenirler. Sakroiliit ile spondilit semptom ve bulgularının ön planda olduğu aksiyel SpA ve periferal eklemlerin tutulumunun ön planda olduğu periferal SpA olarak sınıflandırılır (2). AS spondiloartritlerin prototipidir. Prevalansı \%0,1-\%0,9 arasında değişen oranlarda bildirilmiş olup, romatoid artritin ardından en sık görülen ikinci inflamatuar eklem hastalığıdır (3). Tanı çoğu kez geç konmaktadır. Semptom başlangıcından tanı konulmasına kadar geçen süre ortalama 5-8 yıldır (4).

Spondiloartritlerin tedavisinde farmakolojik ve nonfarmakolojik tedavi yaklaşımlar uygulanır. Tedavinin amacı semptom ve inflamasyonu kontrol altında tutmak ve yapısal hasarı engellemektir. Farmakolojik tedavide ilk basamakta nonsteroid antiinflamatuar ilaç (NSAiD) ve sülfasalazin kullanılır. Illk basamak tedavilerine rağmen aktif hastalık durumunda anti-TNF ilaçlar kullanılmaktadır (5).

Bildiğimiz kadarıyla daha önce ülkemizde Güneydoğu Anadolu'da yapılmış SpA hastalarının klinik özelliklerini inceleyen bir çalışma yoktur. Bu çalışmada Adıyaman Eğitim ve Araştırma Hastanesi'nde aksiyel SpA tanısıyla takip edilen hastaların demografik ve klinik özellikleri, prognostik faktörler ve tedavi yanıtlarının değerlendirilmesi amaçlanmıştır.

\section{Materyal ve Metod}

Bu çalışmada, romatoloji polikliniğinde takipli ASAS aksiyel SpA sınıflama kriterlerine göre tanı konulmuş hastaların dosyaları retrospektif olarak tarandı. Bu kriterler göre 45 yaş öncesinde başlayan 3 aydan uzun süreli bel ağrısı olan görüntüleme yöntemlerinde sakroiliit saptanan hastalarda $\geq 1$ SpA bulgusu olması veya HLA-B27 pozitif olan hastalarda $\geq 2$ SpA bulgusu olması yeterlidir. SpA özellikleri : inflamatuar bel ağrısı, artrit, entezit, üveit, daktilit, psöriazis, inflamatuar barsak hastalığı, NSAiD'lere iyi yanıt, ailede SpA hikayesi, HLA-B27 pozitifliği, C-reaktif Protein (CRP) yüksekliğidir (6).

Çalışmaya 18 yaş üstü tüm hastalar alındı ve çalışmaya toplam 308 hasta dahil edildi. Hastaların demografik özellikleri, tanı anındaki yaşları, semptom başlangıç yaşı, semptomları, periferik tutulum, üveit, HLA-B27 pozitifliği, aile öyküsü, tanı aldıktan sonraki tedaviler ile tedavi yanıtları, ilaçlara bağlı gelişen komplikasyonlar incelendi. Hastalar aldıkları tedavilere göre 3 gruba ayrıldı. NSAiD alanlar grup 1, NSAiD ve sülfasalazin alanlar grup 2, anti- TNF tedavisi alan hastalar (anti-TNF monoterapisi alanlar veya ek olarak NSAiD ve/veya sülfasalazin alanlar) grup 3 olarak sınıflandırıldı. Tedavi almayan (9 hasta) ve sadece sülfasalazin alanlar ( 9 hasta) bu sınıflandırmaya dahil edilmedi.

Hastalık takibinde ve hastalık aktivitesinin değerlendirilmesinde Bath AS Hastalık Aktivite Indeksi (BASDAI) (7), eritrosit sedimantasyon hızı (ESR) ve CRP kullanıldı. Hastaların fonksiyonel durum değerlendirmesinde Bath AS Fonksiyonel İndeksi (BASFI) kullanıldı (8).

Çalışma için etik kurulu onayı Adıyaman Üniversitesi Klinik Çalışmalar Etik kurulundan 2018/8-1 nolu karar ile alınmıştır. İstatistiksel analizler SPSS versiyon 20 yazılımı ile yapıldı. Sürekli değişkenlerin normal dağılıma uygunluğu analitik yöntemle (Kolmogorov-Smirnov) incelendi. Çalışmada sürekli değişkenler medyan (25-75 IQR), kategorik değişkenler sayı (\%) olarak verilmiştir. Normal dağılıma uymayan sürekli değişkenler Spearman korelasyon analizi ile değerlendirildi. İki grubun karşılaştırılmasında Mann Whitney u testi kullanıldı. İkiden fazla grubun karşılaştırılmasında Kruskal Wallis testi kullanıldı. Kategorik değişkenler Ki-kare ve Fisher testleri ile karşılaştırıldı. p $<0,05$ değeri anlamlı olarak kabul edildi.

\section{Bulgular}

Çalışmaya toplam 308 hasta dahil edildi. Hastaların 181'i (\%58,8) erkek, 127'si (\%41,2) kadındı. Medyan (25-75 IQR) yaş 36 (31-45) idi. ilk semptomdan tanı almalarına kadar geçen süre (tanıda gecikme süresi) medyan (25-75 IQR) 4 $(3-5,5)$ yıldı. Tanı alma yaşı ise medyan (25-75 IQR) 31 (27$40)$ idi. HLA-B27 hastaların 110'nunda çalışılmıştı, 48 hastada $(\% 43,6)$ pozitifti. Aile öyküsü olanların oranı $\% 12,3$ (38) idi (tablo 1). Hastalardan $21^{\prime}$ inde $(\% 6,8)$ aksiyel SpA ile birlikte psöriazis , 5 hastada (\%1.6) ise birlikte inflamatuar barsak hastalığı vardı.

Klinik bulgular açısından değerlendirildiğinde $62(\% 20,1)$ hastada entezit saptandı. Periferik eklem tutulumu 20 hastada $(\% 6,5)$ mevcuttu. Üveit ise 20 hastada $(\% 6,5)$ gözlendi. Sakroiliit 203 hastada $(\% 65,9)$ manyetik rezonans (MR) ile, 105 hastada $(\% 34,1)$ ise direkt grafi ile saptanmıştı. Hastalarda radyografik kalça eklemi tutulum oranı \%3,9 (12) idi. Eşlik eden hastalıklarda en sık fibromiyalji vardı ( $25-\% 8,1)$. Onu sırasıyla ailevi akdeniz ateşi (FMF) ( 5 - \%1,6), hipertansiyon $(2-\% 0,6)$ ve diyabet $(2$ $\% 0,6)$ izlemektedir.

Hastalarda takip parametreleri medyan (25-75 IQR) BASDAI 4,2 (3,3-5,5), BASFI 3,7 $(3,02-5,2)$ bulundu. ESR medyan (25-75 IQR) 13 ( 11-13) mm/st idi. CRP medyan (25-75 IQR) $3,1(2,2-6,1) \mathrm{mg} / \mathrm{dl}$ idi. Parametreler arasındaki ilişkiye bakıldığında BASDAl ve BASFI arasında $(r=0,703$, $p=0,000)$, BASFI ile CRP arasında $(r=0,131, p=0,021)$ ve ESR ile CRP arasında $(r=0,484, p=0,000)$ pozitif korelasyon saptandı. BASDAI ile CRP $(r=0,063, p=0,274)$ ve ESR $(r=0,018, p=0,753)$ arasında istatiksel olarak anlamlı ilişki bulunmadı. BASFI ile ESR arasında $(r=0,089, p=0,122)$ istatiksel olarak anlamlı ilişki bulunmadı.

Hastalar HLA-B27 pozitifliğine göre karşılaştırıldığında yaş, 
tanı yaşı, periferik eklem tutulumu, entezit, üveit, BASDAI, ESR ve CRP düzeyleri açısından benzerdi (sırasıyla $p=0,845, p=0,583, p=0,171, p=0,826, p=0,236, p=0,185$, $p=0,452, p=0,740)$. HLA-B27 pozitif olan hastalarda istatiksel anlamlı olarak erkek oranı $(32, \% 66,7)$ kadınlardan $(16, \% 33,3)$ yüksekti $(p=0,025)$. Ayrıca HLA-B27 pozitif olan hastalarda istatiksel anlamlı olarak BASFI skoru daha yüksek $(p=0,019)$ ve tanıda gecikme süresi daha düşüktü ( $p=0,015)$ (Tablo 2).

Tablo 1. Hastaların demografik ve klinik özellikleri

\begin{tabular}{ll}
\hline & Hastalar (n=308) \\
\hline Yaş & $36(31-45)$ \\
Tanı yaşı & $31(27-40)$ \\
Tanıda gecikme süresi (yıl) & $4(3-5,5)$ \\
Cinsiyet & \\
$\quad$ Erkek & $181(\% 58,8)$ \\
$\quad$ Kadın & $127(\% 41,2)$ \\
HLA B27 pozitifliği & $48(\% 43,6)$ \\
Aile öyküsü & $38(\% 12,3)$ \\
Periferik artrit & $20(\% 6,5)$ \\
Entezit & $62(\% 20,1)$ \\
Üveit & $20(\% 6,5)$ \\
Kalça eklemi tutulumu & $12(\% 3,9)$ \\
BASDAl & $4,2(3,3-5,5)$ \\
BASFI & $3,7(3,02-5,2)$ \\
ESR ( mm/st) & $13(11-13)$ \\
CRP ( mg/dl) & $3,1(2,2-6,1)$ \\
\hline Değerler medyan (25-75 QR) veya sayı $(\%)$ olar verilmistir.
\end{tabular}

Değerler medyan (25-75 IQR) veya sayı (\%) olarak verilmiştir.

ESR: eritrosit sedimantasyon hIzI, CRP: c-reaktif protein, BASDAl: Bath AS Hastalık Aktivite Indeksi, BASFI: Bath AS Fonksiyonel Indeksi.

Tablo 2. HLA B27 pozitifliğine göre hastaların klinik özelliklerinin karşılaştırılması

\begin{tabular}{llll}
\hline & $\begin{array}{c}\text { HLA B27 pozitif } \\
(\mathbf{n}=\mathbf{4 8})\end{array}$ & $\begin{array}{c}\text { HLA B27 negatif } \\
(\mathbf{n}=\mathbf{6 2})\end{array}$ & p değeri \\
\hline Yaş & $37,5(32,2-46)$ & $37(32-46)$ & 0,845 \\
Tanı yaşı & $33(28,2-40,7)$ & $33,5(27,7-40)$ & 0,583 \\
Tanıda gecikme & $3,7(3-5,7)$ & $5(3,8-6,2)$ & $0,015^{*}$ \\
süresi (yıl) & & & \\
Cinsiyet & & & \\
$\quad$ Erkek & $32(\% 66,7)$ & $28(\% 45,2)$ & $0,025^{*}$ \\
$\quad$ Kadın & $16(\% 33,3)$ & $34(\% 54,8)$ & \\
Periferik artrit & $1(\% 2,1)$ & $5(\% 8,1)$ & 0,171 \\
Entezit & $10(\% 20,8)$ & $14(\% 22,6)$ & 0,826 \\
Üveit & $5(\% 10,4)$ & $2(\% 3,2)$ & 0,236 \\
BASDAl & $4,2(3,3-5,2)$ & $4,1(3,2-5)$ & 0,185 \\
BASFI & $4,2(3,1-5,9)$ & $3,2(2,3-4,2)$ & $0,019 *$ \\
ESR (mm/st) & $13(11,2-18,7)$ & $13(10-17)$ & 0,452 \\
CRP (mg/dl) & $3(2-6,3)$ & $3(2,3-7)$ & 0,740 \\
\hline
\end{tabular}

Değerler medyan (25-75 IQR) veya sayı (\%) olarak verilmiştir. ${ }^{*} p<0,05$ istatistiksel olarak anlamlı kabul edildi.

ESR: eritrosit sedimantasyon hIzı, CRP: c-reaktif protein, BASDAI: Bath AS Hastalık Aktivite indeksi, BASFI: Bath AS Fonksiyonel indeksi.

Hastalar cinsiyete göre karşılaştırıldığında yaş, tanı yaşı, tanıda gecikme süresi, periferik eklem tutulumu, entezit, üveit, BASDAI, BASFI, ESR ve CRP düzeyleri açısından benzerdi (sırasıyla $p=0,331, p=0,220, p=0,238, p=0,078$, $p=0,900, p=0,908, p=0,862, p=0,856, p=0,353, p=0,518)$. Buna karşın HLA-B27 pozitifliği erkeklerde $(32, \% 53,3)$ kadınlara $(16, \% 32,0)$ göre istatiksel anlamlı olarak yüksekti $(p=0,025)$ (Tablo 3).

Tedavide ilaçlardan en fazla kullanılanı 99 hasta $(\% 32,1)$ ile NSAID+sülfasalazin kombinasyonuydu. Onu sırasıyla 97 $(\% 31,5)$ NSAiD, $70(\% 22,7)$ anti-TNF+NSAiD, 15 (\%4,9) anti-TNF, $9(\% 2,9)$ NSAID+sülfasalazin+anti-TNF ve 9 $(\% 2,9)$ sülfasalazin izlemekteydi. 9 hasta $(\% 2,9)$ ise tedavi almıyordu. Anti-TNF tedavisi alan hastaların dağılımı 25 $(\% 8,1)$ adalimumab, $25(\% 8,1)$ etanercept, $22(\% 7,1)$ infliksimab, $14(\% 4,5)$ golimumab ve $7(\% 2,3)$ sertolizumab şeklindeydi. Hastaların \%6,8'i (21) steroid tedavisi almaktaydı. NSAiD kullanan hastalarda en sık rastlanan yan etki gastrointestinal intoleranstı. Sülfasalazin kullananlarda cilt reaksiyonu $7(\% 2,3)$ ve gastrointestinal yakınmalar görülmüştü.

Tedavi grupları arasında ( grup 1,2,3) BASDAI, BASFI, CRP, ESR, yaş, tanı yaşı, tanıda gecikme süresi, cinsiyet, HLAB27 pozitifliği, periferik artrit, entezit, üveit açısından anlamlı farklılık yoktu (sırasıyla $p=0,064, p=0,066, p=0,429$ $p=0,979, p=0,069, p=0,123, p=0,758, p=0,110, p=0,196$, $p=0,089, p=0,340, p=0,438$ )(Tablo 4).

\section{Tartışma}

Spondiloartrit grubu hastalıklar toplumun \%2-3'ünü etkileyen kronik inflamatuar hastalıklardır (2). SpA' da klinik, genetik ve çevresel faktörleri araştırmak hastalığın patogenezini anlamak açısından önemini korumaktadır. Biz bu çalışmada literatür bilgileri ülkemizde kısıtlı olan aksiyel SpA'nın güneydoğu Anadolu bölgesinde yer alan Adıyaman ili verilerini sunmayı amaçladık.

Spondiloartritte birlikte psöriazis varsa psöriatik artrit, inflamatuar barsak hastalığı varsa enteropatik artrit kabul edilir. Klinik bulgularda sakroiliit ve spondilit baskın olan aksiyel SpA 'ya sakroiliit direkt grafide saptanmışsa radyografik aksiyel SpA denir. Sakroiliit MR'da saptanmışsa hasta non radyografik aksiyel SpA kabul edilir. Eşlik eden hastalık yok ve SpA radyografik ise AS olarak adlandırımaktadır (2,9). Çalışmamızda 105 hastada $(\% 34,1)$ radyografik aksiyel SpA (AS), 203 hastada $(\% 65,9)$ non radyografik aksiyel SpA, 21'inde $(\% 6,8)$ aksiyel tutulumlu psöriatik artrit ve 5 hastada (\%1.6) ise aksiyel tutulumlu enteropatik artrit vardı.

Tablo 3. Cinsiyete göre hastaların klinik özelliklerinin karşılaştırılması

\begin{tabular}{llll}
\hline & \multicolumn{1}{c}{$\begin{array}{c}\text { Kadın } \\
(\mathbf{n = 1 2 7})\end{array}$} & $\begin{array}{c}\text { Erkek } \\
(\mathbf{n = 1 8 1 )}\end{array}$ & $\begin{array}{c}\text { p de- } \\
\text { ğeri }\end{array}$ \\
\hline Yaş & $37(31-46)$ & $35(31-43)$ & 0,331 \\
Tanı yaşı & $33(28-40)$ & $31(27-39)$ & 0,220 \\
Tanıda gecikme süresi (yıl) & $4(3-6)$ & $4(3-5)$ & 0,238 \\
HLA B27 pozitifliği & $16(\% 32,0)$ & $32(\% 53,3)$ & $0,025 *$ \\
Periferik artrit & $12(\% 9,4)$ & $8(\% 4,4)$ & 0,078 \\
Entezit & $26(\% 20,5)$ & $36(\% 19,9)$ & 0,900 \\
Üveit & $8(\% 6,3)$ & $12(\% 6,6)$ & 0,908 \\
BASDAl & $4,3(3,3-6)$ & $4,2(3,3-5,5)$ & 0,862 \\
BASFI & $3,6(3,1-5,1)$ & $3,8(2,7-5,4)$ & 0,856 \\
ESR (mm/st) & $13(11-19)$ & $13(11-18)$ & 0,353 \\
CRP (mg/dl) & $2(2-6)$ & $3(2-6)$ & 0,518 \\
\hline
\end{tabular}

Değerler medyan (25-75 IQR) veya sayı (\%) olarak verilmiştir. ${ }^{*} p<0,05$ istatistiksel olarak anlamlı kabul edildi. ESR: eritrosit sedimantasyon hızı, CRP: c-reaktif protein, BASDAI: Bath AS Hastalık Aktivite indeksi, BASFI: Bath AS Fonksiyonel Indeksi. 
Ankilozan spondilitte hastalık bulguları geç adolesan veya erken erişkinlik dönemindedir başlar ve yaklaşık 28 yaşlarında zirve yapar. 16 yaş öncesi veya 45 yaş sonrası başlaması çok nadirdir (10). Hastaların \%20'sinde pozitif aile öyküsü vardır. Cinsiyetler dağılımında eski çalışmalarda erkek-kadın oranının 2:1 ile 3:1 arasında gösterilmiştir. Ancak son zamanlarda yapılan Amerikan kökenli bir çalışmada erkek ve kadınlar arasında istatistiksel olarak anlamlı fark bulunmamıştır $(11,12)$. Ülkemizde yapılan bir çalışmada ise erkek/kadın oranı 3,4/1 bulunurken, ortalama tanı yaşı 32,4 tanıda gecikme süresi ise 4,6 yıl olarak tespit edilmiştir (13). Çalışmamızda hastaların yaş medyan (25-75 IQR) 36 (31-45) literatürle uyumludur. Tanı yaşı [medyan 31 (IQR : 27-40)] ve tanıda gecikme süresi [medyan 4 (IQR : 3-5,5) yıl] ülkemizde yapılan çalışmaya benzerdir ve hastalığın genç erişkinlik dönemde başladığını göstermektedir. Aile öyküsü çalışmamızda literatür \%12,3 bulundu; bu sonuç önceki çalışmalara yakındır. Bizim çaıışmamızda erkek hasta oranı $(\% 58,8)$ kadın hasta oranından $(\% 41,2)$ yüksek bulunmuştur ve son zamanlarda yapılan yeni çalışmalara benzer şekilde farkın azaldığı düşündürmektedir.

Spondiloartrit kliniğinde başlıca muskuloskeletal semptomlar, cilt ve mukoza lezyonları, göz ve barsak mukozası tutulumudur. En sık görülen muskuloskeletal lezyonlar inflamatuar bel ağrısı, periferik artrit, daktilit ve entezittir. Periferik artrit çoğunlukla alt ekstremite büyük eklemleri tutan, asimetrik oligoartrit şeklinde görülür (14). Bir çalışmada periferik eklem tutulumu hastaların \%10-20 sinde olduğu ve hastalık seyrinde \%30-40'lara vardığı bildirilmiştir. Bir başka çalışmada ise periferik artrit \%47 olarak saptanmıştır. Ülkemizde yapılan bir çalışmada ise hastaların \%15,6'sında periferik eklem tutulumu bulunmuştur $(13,15,16)$. Entezit en sık topuk ağrı ve şişliği ile seyreden aşil tendinit olarak prezente olur (17). Yapılan bir çalışmada entezit sıklığı \%42 olarak bildirilmiştir (16). Kalça ağrısı AS hastalarının \%25-35'inde izlenir ve kötü prognoz ile ilişkilidir. Zaman içinde kalçada fleksiyon deformiteleri gelişebilir bazı hastalarda kalça replasman cerrahisi gerekebilir (18). Mevcut çalışmada periferik artrit (\%6.5), entezit $(\% 20,1)$ ve kalça eklemi tutulumu $(\% 3,9)$ bu verilere göre daha düşük oranda bulunmuştur. Hasta sayısının az olması veya etnik nedenler bunun nedeni olabilir.

Anterior üveit AS' en sık görülen ekstraartiküler tutulumdur. AS hastalarının \%15-33'ünde hastalığın herhangi bir döneminde görülebilir. Gözde kızarıklık ve ağrı ile gösteren anterior üveit tekrarlayıcı vasıftadır (19). Kore kökenli bir çalışmada üveit oranı \%29 bulunurken ülkemizde yapılan bir çalışmada \%12,8 oranında bulunmuştur $(13,16)$. Çalışmamızda üveit oranı \%6.5'dir ve önceki çalışmalara göre düşük görünmektedir. Çalışmaya alınan hasta sayısının azlığı, etnik ve ve çevresel faktörler bunda etkili olabileceğini düşünüyoruz.

Spondiloartrit ile HLA-B27 arasında güçlü bir ilişki bulunmaktadır. Bu ilişki AS'de en belirgindir. SpA grubundaki di- ğer hastalıklarda ise azalmış sıklıkta da olsa HLA-B27 ilişkisi mevcuttur. Toplumda HLA-B27 sıklığı \%6-8 iken, AS'li hastalarda kuzey Avrupa ülkelerinde \%90-95 bulunmaktadır $(1,3)$. Ancak batılı ülkelerle göre ülkemizde HLAB27'nin daha az oranda pozitif olduğu gösterilmiştir (20). Ayrıca HLA-B27 ile klinik özellikler arasında da bağlantı vardır.

Tablo 4. Tedavi yanıtının değerlendirilmesi ve grupların karşılaştırılması

\begin{tabular}{|c|c|c|c|c|}
\hline & $\begin{array}{c}\text { NSAiD } \\
\text { (Grup 1, } \\
\mathrm{n}=97 \text { ) }\end{array}$ & $\begin{array}{l}\text { NSAiD+sülfa- } \\
\text { salazin } \\
\text { (Grup 2, } \\
\text { n=99) }\end{array}$ & $\begin{array}{c}\text { Anti-TNF } \pm \\
\text { (NSAiD } \pm \text { sülfa- } \\
\text { salazin) } \\
\text { (Grup } 3, n=94 \text { ) }\end{array}$ & $\begin{array}{c}p \\
\text { değeri }\end{array}$ \\
\hline Yaş & $\begin{array}{c}36 \\
(31,5-44)\end{array}$ & $\begin{array}{c}36 \\
(32-46)\end{array}$ & $\begin{array}{c}35 \\
(31-45,2)\end{array}$ & 0,069 \\
\hline Tanı yaşı & $\begin{array}{c}32 \\
(28-40)\end{array}$ & $\begin{array}{c}31 \\
(28-40)\end{array}$ & $\begin{array}{c}31 \\
(24,7-39,2)\end{array}$ & 0,123 \\
\hline $\begin{array}{l}\text { Tanıda ge- } \\
\text { cikme sü- } \\
\text { resi (yıl) }\end{array}$ & $\begin{array}{c}4 \\
(3-6)\end{array}$ & $\begin{array}{c}4 \\
(3-6)\end{array}$ & $\begin{array}{c}4 \\
(3-5,2)\end{array}$ & 0,758 \\
\hline \multicolumn{5}{|l|}{ Cinsiyet } \\
\hline Erkek & $\begin{array}{c}55 \\
(\% 56,7)\end{array}$ & $\begin{array}{c}52 \\
(\% 52,5)\end{array}$ & $\begin{array}{c}62 \\
(\% 65,9)\end{array}$ & 0,110 \\
\hline Kadın & $\begin{array}{c}42 \\
(\% 43,3)\end{array}$ & $\begin{array}{c}47 \\
(\% 47,5)\end{array}$ & $\begin{array}{c}32 \\
(\% 34,1)\end{array}$ & \\
\hline $\begin{array}{l}\text { HLA B27 } \\
\text { pozitifliği }\end{array}$ & $\begin{array}{c}19 \\
(\% 37,5)\end{array}$ & $\begin{array}{c}8 \\
(\% 36,6)\end{array}$ & $\begin{array}{c}15 \\
(\% 45,9)\end{array}$ & 0,196 \\
\hline $\begin{array}{l}\text { Periferik } \\
\text { artrit }\end{array}$ & $\begin{array}{c}5 \\
(\% 5,2)\end{array}$ & $\begin{array}{c}7 \\
(\% 7,1)\end{array}$ & $\begin{array}{c}6 \\
(\% 6,3)\end{array}$ & 0,089 \\
\hline Entezit & $\begin{array}{c}17 \\
(\% 17,5)\end{array}$ & $\begin{array}{c}23 \\
(\% 23,2)\end{array}$ & $\begin{array}{c}17 \\
(\% 18)\end{array}$ & 0,340 \\
\hline Üveit & $\begin{array}{c}5 \\
(\% 5,2)\end{array}$ & $\begin{array}{c}8 \\
(\% 8,1)\end{array}$ & $\begin{array}{c}6 \\
(\% 6,3)\end{array}$ & 0,438 \\
\hline BASDAI & $\begin{array}{c}4,2 \\
(3,3-5,4)\end{array}$ & $\begin{array}{c}4,4 \\
(3,5-6,1)\end{array}$ & $\begin{array}{c}3,8 \\
(3,2-5,1)\end{array}$ & 0,064 \\
\hline BASFI & $\begin{array}{c}3,8 \\
(3,1-5,2)\end{array}$ & $\begin{array}{c}3,8 \\
(3,1-5,2)\end{array}$ & $\begin{array}{c}3,6 \\
(2,5-5,3)\end{array}$ & 0,066 \\
\hline $\begin{array}{l}\text { ESR } \\
(\mathrm{mm} / \mathrm{st})\end{array}$ & $\begin{array}{c}12 \\
(9-15)\end{array}$ & $\begin{array}{c}14 \\
(12-19)\end{array}$ & $\begin{array}{c}13 \\
(10-19)\end{array}$ & 0,979 \\
\hline $\begin{array}{l}\text { CRP } \\
(\mathrm{mg} / \mathrm{dl})\end{array}$ & $\begin{array}{c}3 \\
(2-5,6)\end{array}$ & $\begin{array}{c}3,2 \\
(2,1-6,3)\end{array}$ & $\begin{array}{c}3 \\
(2-6,6)\end{array}$ & 0,429 \\
\hline
\end{tabular}

Değerler medyan (25-75 IQR) veya sayı (\%) olarak verilmiştir. ${ }^{*} p<0,05$ istatistiksel olarak anlamlı.

Anti-TNF: Tümör nekrozis faktör inhibitörleri, NSAID: nonsteroid antiinflamatuar ilaç, ESR: eritrosit sedimantasyon hızı, CRP: c-reaktif protein, BASDAI: Bath AS Hastalık Aktivite Indeksi, BASFI: Bath AS Fonksiyonel indeksi

HLA-B27'nin artrit ve üveit ile ilişkili olduğu bulunmuştur (21). Bunu yanında ülkemizde yapılan bir çalışmada FMF hastalarında HLA-B27 'nin sakroiliit gelişmesinde ve SpA şiddetinde rol oynayabileceğini öne sürmüşlerdir (22). Bizim hastalarımızda HLA-B27 pozitifliği \%43,6'dı, fakat sadece 110 hastada test çalışılmıştı. Buna rağmen önceki Türkiye çalışmalarında de bildirildiği gibi ülkemizde Avrupa ülkelerine göre daha az oranda HLA-B27 pozitifliği olduğu söylenebilir. Öte yandan çalışmamızda HLA-B27 pozitif ve negatif olan grup kıyasladığımızda ; klinik bulgular (periferik artrit, entezit, üveit) ve hastalık aktivite parametreleri ( BASDAI, ESR, CRP) benzerdi. Buna karşın HLAB7 pozitif olanlarda tanıda gecikme süresi daha kısa $(p=0,015)$, erkek cinsiyet hakimiyeti daha fazla $(\% 66,7$, $p=0,025)$ ve fonksiyonel indeksleri (BASFI) daha yüksekti $(p=0,019)$. Daha önce yapılan benzer bir çalışmada ise Arevalo ve ark. periferik artriti HLA-B27 negatif grupta daha sık saptamışlar ancak entezit ve üveit açısından iki 
grup arasında anlamlı bir farklılık bulamamışlardır (23). Bu sonuçlara göre HLA-B27'nin hastalığın kötü seyirli olduğu erkeklerde daha yüksek oranda görüldüğünü, şiddetli semptomlar neden olarak tanı süresinin kısaltabileceğini ve hızlı hastalık seyri olduğu için hastaların fonksiyonel durumlarında kötüleşmeye neden olabileceğini göstermektedir.

Ankilozan spondilitte cinsiyet hastalık prezantasyonunda farklılığa yol açar. Hastalık kadınlarda genelde daha hafif seyreder, daha geç yaşlarda başlar ve tanı daha geç olmaktadır (24). Her ne kadar çalışmada cinsiyetler arasında tanı yaşı, tanıda gecikme süresi ve klinik bulgular (periferik artrit, entezit, üveit) açısından anlamlı fark saptanmasa da; hastalık aktivite parametreleri ( BASDAI, ESR, CRP) ve BASFI değerleri erkeklerde daha yüksekti. Ayrıca erkek hastalarda istatiksel olarak anlamlı olarak, SpA şiddetinde rolü olduğu düşünülen HLA-B27 pozitifliği (\%53,3 , $p=0,025)$ yüksekti. Neticede erkek cinsiyette daha şiddetli hastalık aktivitesi ve daha kötü prognoz görülebilir.

Spondiloartritlerde özellikle aksiyel tutulumu olan hastalarda ilk basamak tedavi NSAID'dir. NSAID'lerin hem analjezik hem de anti inflamatuar etkileri vardır. En sık yan etkileri gastrointestinal sistemde rahatsızlık, gastrit, ülser, hepatik ve renal fonksiyon bozukluğudur (25). Sülfasalazin aksiyel belirtilerde etkin değildir ancak periferik eklem tutulumunda ve anterior üveiti olan hastalarda faydalı bulunmuştur $(25,26)$. Kullanıma girmesiyle SpA tedavisinde yeni bir dönem başlatan anti-TNF ilaçlar büyük bir oranında semptom ve bulguların düzelmesine yardımcı olmaktadır. Anti-TNF'ler genellikle NSAiD ve sülfasalazin etkin olmadığı durumlarda kullanılırlar (27). Hasta grubumuzda mevcut önerilere uygun olarak tedaviler kullanılmaktaydı. Tedavi gruplarını karşılaştırdığımızda grup 1 (NSAID), grup 2 (NSAiD+sülfasalazin) ve grup 3 (anti-TNF) arasında demografik, klinik, laboratuvar, aktivite skorları ve fonksiyonel değerlendirme skoru parametrelerinde istatiksel olarak anlamlı fark yoktu. Ama anti-TNF grubunda ortalama değer olarak erkek baskınlığı (\%65), HLA-B27 pozitifliği $(\% 45,9)$ daha yüksekti. O yüzden anti-TNF grubunda daha kötü prognoz potansiyeli olan hastalar olmasına rağmen tedavi etkisiyle hastalık aktivitesi kontrol altına alındığı ve hastaların fonksiyonel kapasiteleri artırdığı söylenebilir.

C-reaktif protein ve ESR' nin yanında hastalık aktivite değerlendirilmesinde yaygın olarak kullanılan indeks BASDAI'dir. BASDAI hastanın son bir haftadaki eklem ağrıları, genel durumunu, yorgunluk düzeyini, sabah tutukluğunu değerlendiren bir soru ölçeğidir. BASDAI indeksinde 4'ün üzerindeki sonuçlar aktif hastalık göstergesidir (7). Hastalarının fonksiyonel durum değerlendirmesi için BASFI geliştirilmiştir. BASFI, hastaların son bir haftalık günlük yaşamlarındaki fonksiyonlarını saptamak için hastalara soruların değerlendirilmesiyle elde edilmektedir (8). Çalışmada ESR ile CRP arasında $(p=0,000)$ pozitif ilişki varken, BASDAI ile CRP ve ESR arasında istatiksel olarak anlamlı ilişki bulunmadı. Bu bize hastalık aktivitesi yüksek olsa bile akut faz yanıtının yüksek olmayabileceğini göstermektedir. BASDAI ve BASFI arasında $(p=0,000)$ ve BASFI ile CRP arasındaki $(p=0,021)$ pozitif korelasyon ise fonksiyonel olarak kısıtlanmış hastalarda genel olarak hastalık aktivitesinin yüksek olduğunu göstermektedir.

Sonuç olarak çalışmamıza göre; SpA'da 2-3. dekad ve erkek cinsiyet ön planda görünmektedir. HLA-B27 pozitifliği önceki Türkiye verileri gibi Avrupa'ya göre düşüktür. HLAB27 pozitifliği ve erkek cinsiyet kötü prognoz etkeni olabilirler. SpA'da konvansiyonel tedaviye yanıt olmadığında anti-TNF tedavi başlanması değerlendirilmelidir. Uygun hastalarda Anti-TNF tedaviler klinik belirti ve bulguları iyileştirmekte ve hastanın fiziksel fonksiyonunu iyileştirmektedir. Ülkemizde SpA'lı hastalarda klinik özellikler, HLAB27 sıklığı ve tedavi yanıtı ilişkisini inceleyen daha geniş popülasyonlu çalışmalar yapılması gerekmektedir.

Çalışmamızın bazı kısıtlılıkları göz önünde bulundurulmalıdır. Hasta sayısının az olması dışında HLA-B27 her hastaya yapılmamış olması kısıtlılık olarak düşünülebilir. Ayrıca daha uzun takip süreli hasta verileri prognoz ve tedavi yanıtları açısından daha yol gösterici olabilir.

Etik onam: Çalışma için etik kurulu onayı Adıyaman Üniversitesi Klinik Çalışmalar Etik kurulundan 20/11/2018 tarih ve 2018/8-1 nolu karar ile alınmıştır.

\section{Yazar Katkıları:}

Konsept: $0 . Z$.

Literatür Tarama O.Z.

Tasarımı: O.Z.

Veri toplama: O.Z.

Veri analizi ve yorumlama: O.Z. , N.E.

Makale yazımı: O.Z. , N.E. , I.H.T

içeriğin eleştirel incelenmesi: O.Z. , N.E. , i.H.T

Çıkar Çatışması: Yazarlar çıkar çatışması beyan etmemişlerdir. Finansal Destek: Yazarlar finansal destek beyan etmemişlerdir.

\section{Kaynaklar}

1. Keser G. Spondiloartritlerin sınıflandırılması. Türkiye Klinikleri İmmünoloji Romatoloji. 2004;4(1):1-12.

2. Taurog JD, Chhabra A, Colbert RA. Ankylosing Spondylitis and Axial Spondyloarthritis. N Engl J Med. 2016; 374(26): 2563-2574.

3. Braun $J$, Bollow $M$, Remlinger $G$, Eggens $U$, Rudwaleit $M$, Distler A, et al. Prevalence of spondylarthropathies in HLAB27 positive and negative blood donors. Arthritis Rheum. 1998;41(1):58-67.

4. Guillemin F, Briancon S, Pourel J, Gaucher A. Long-term disability and prolonged sick leaves as outcome measurements in ankylosing spondylitis. Possible predictive factors. Arthritis Rheum. 1990;33(7):1001-6.

5. B Elbey. Ankilozan spondilitli hastalarda güncel tedavi yakIaşımları. Dicle Tıp Dergisi. 2015;42(1):123-127.

6. Rudwaleit $M$, van der Heijde $D$, Landewé $R$, Listing J, Akkoc $\mathrm{N}$, Brandt J, et al. The development of Assessment of Spondyloarthritis international Society classification criteria for axial spondyloarthritis (part II): Validation and final selection. Ann Rheum Dis. 2009;68(6):777-783.

7. Garrett $S$, Jenkinson $T$, Kennedy LG, Whitelock H, Gaisford $P$, Calin A. A new approach to defining disease status in 
ankylosing spondylitis: the Bath Ankylosing Spondylitis Disease Activity Index. J Rheumatol. 1994;21(12):2286-91.

8. Calin A, Garrett S, Whitelock H, Kennedy LG, O'Hea J, Mallorie $\mathrm{P}$, et al. A new approach to defining functional ability in ankylosing spondylitis: the development of the Bath Ankylosing Spondylitis Functional Index. I Rheumatol. 1994;21(12):2281-5.

9. Raychaudhuri SP, Deodhar A. The classification and diagnostic criteria of ankylosing spondylitis. J Autoimmun. 2014;48(49): 128-33.

10. Gran JT, Husby G. The Epidemiology of ankylosing spondylitis. Semin Arthritis Rheum. 1993;22(5):319-34.

11. Reveille JD, Hirsch R, Dillon CF, Carroll MD, Weisman MH. The prevalence of HLA-B27 in the US: data from the US National Health and Nutrition Examination Survey, 2009. Arthritis Rheum. 2012;64(5):1407.

12. Kidd B, Mullee M, Frank A, Cawley M. Disease expression of ankylosing spondylitis in males and females. J Rheumatol. 1988;15(9):1407-1409.

13. Çağlar N, Burnaz Ö, Akın T, Özgönenel L, Çetin E, Aytekin $E$, ve ark. Ankilozan spondilitli hastalara ait demografik veriler, klinik özellikler ve medikal tedavileri. İstanbul Tıp Dergisi. 2011;12(1):19-2.

14. Dougados $M$, van der Linden $S$, Juhlin $R$, Huitfeldt $B$, Amor B, Calin A, et al. The European Spondylarthropathy Study Group preliminary criteria for the classification of spondylarthropathy. Arthritis Rheum. 1991;34(10):1218.

15. Ginsburg WW, Cohen MD. Peripheral arthritis in ankylosing spondylitis. A review of 209 patients followed up for more than 20 years. Mayo Clin Proc. 1983;58(9):593-6.

16. Kim TJ, Kim TH. Clinical spectrum of ankylosing spondylitis in Korea. Joint Bone Spine. 2010;77(3):235-40.

17. Rudwaleit $M$, van der Heijde $D$, Landewé $R$, Akkoc $N$, Brandt J, Chou CT, et al. The Assessment of SpondyloArthritis International Society classification criteria for peripheral spondyloarthritis and for spondyloarthritis in general. Ann Rheum Dis. 2011;70(1):25-31.

18. Vander Cruyssen B, Muñoz-Gomariz E, Font $P$, Mulero J, Vlam K, Boonen A, et al. Hip involvement in ankylosing spondylitis: epidemiology and risk factors associated with hip replacement surgery. Rheumatology (Oxford). 2010;49(1):73-81.

19. Sampaio-Barros PD, Conde RA, Bonfiglioli R, Bertolo MB, Samara AM. Characterization and outcome of uveitis in 350 patients with spondyloarthropahies. Rheumatol Int. 2006;26(12): 1143-1146.

20. Akar S, Igci YZ, Sari I, Geyik E, Tas M, Solmaz D, et al. Do major histocompatibility complex tag single nucleotide polymorphisms accurately identify HLA-B27 in the Turkish population? Int J Rheum Dis. 2017;20(12):2035-2039.

21. Breban M, Said-Nahal R, Hugot JP, Miceli-Richard C. Familial and genetic aspects of spondyloarthropathy. Rheum Dis Clin North Am. 2003;29(3): 575-94.

22. Kaşifoğlu $T$, Çalışır $C$, Cansu D, Korkmaz C. The frequency of sacroiliitis in familial Mediterranean fever and the role of HLA-B27 and MEFV mutations in the development of sacroiliitis. Clin Rheumatol. 2009;28(1):41-46.

23. Arévalo $M$, Gratacós Masmitjà J, Moreno $M$, Calvet J, Orellana C, et al ; REGISPONSER group. Influence of HLA-B27 on the Ankylosing Spondylitis phenotype: results from the REGISPONSER database. Arthritis Res Ther. 2018;20(1):221.
24. Lee W, Reveille JD, Weisman MH. Women with ankylosing spondylitis. Arthritis Rheum. 2008;59(3):449-454.

25. Lavie F, Pavy S, Dernis E, Goupille P, Cantagrel A, Tebib J, et al. Pharmacotherapy (excluding biotherapies) for ankylosing spondylitis: development of recommendations for clinical practice based on published evidence and expert opinion. Joint Bone Spine. 2007;74(4):346-352.

26. Ozgocmen S, Akgul O, Altay Z, Altindag O, Baysal O, Calis $\mathrm{M}$, et al. Expert opinion and key recommendations for the physical therapy and rehabilitation of patients with ankylosing spondylitis. Int J Rheum Dis. 2012;15(3):229-38.

27. Baraliakos $X$, Listing J, Brandt J, Zink A, Alten R, Burmester $G$, et al. Clinical response to discontinuation of anti-TNF therapy in patients with ankylosing spondylitis after 3 years of continuous treatment with infliximab. Arthritis Research \& Therapy. 2005;7(3):439-44. 